\title{
A Look At The Merchant Marine Act Of 1920: Is It Time For The U.S. To Change Course?
}

Rachelle F. Cope, Southeastern Louisiana University, USA

John M. Woosley, Southeastern Louisiana University, USA

Robert F. Cope III, Southeastern Louisiana University, USA

\begin{abstract}
Due to recent changes in global shipping, we investigate the Merchant Marine Act of 1920 - also known as the Jones Act. When constructed, our governing body decided that the Act was necessary for the country's naval defenses and for proper growth of foreign and domestic commerce. The plan was for the fleet to be owned and operated privately by citizens of the United States. However, in today's economic conditions some are wondering if the Jones Act is a liability to foreign commerce. In our work, we explore the advantages of naval defense and shipbuilding as well as the disadvantages on commerce and U.S. transportation infrastructure. To conclude, we offer opinions for policy changes to create a more level playing field for the U.S. to compete in global logistics.
\end{abstract}

Keywords: Merchant Marine Act of 1920; Jones Act; Global Logistics; Container Shipping

\section{INTRODUCTION}

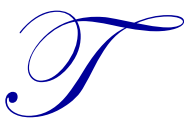

he Merchant Marine Act of 1920, commonly referred to as the Jones Act, is a U.S Federal statute that regulates maritime commerce in U.S. waters and between U.S. ports (Brackins, 2009). Two parts of the Jones Act are of specific importance. The first part heavily supports American built, owned, and staffed ships. This was accomplished by restricting shipping and passenger trade within the U.S. to American-owned or American-flagged ships, and specified that at least $75 \%$ of a ship's crew must comprise American citizens. Thus, foreign vessels cannot travel port-to-port in the U.S.

In the second part of the Jones Act, the use of foreign parts and labor in ship construction and repair was also greatly restricted. This section of the Jones Act was created to produce a strong, well staffed merchant marine that could be responsible for efficiently serving the U.S. (Smith, 2010).

The intent and purpose of the Jones Act has been specifically outlined in its preamble:

"It is necessary for the national defense and for the proper growth of its foreign and domestic commerce that the United States shall have a merchant marine of the best equipped and most suitable types of vessels sufficient to carry the greater portion of its commerce and serve as a naval or military auxiliary in time of war or national emergency, ultimately to be owned and operated privately by citizens of the United States; and it is declared to be the policy of the United States to do whatever may be necessary to develop and encourage the maintenance of such a merchant marine" (1800JonesAct, 2008).

Overall, effects of the Jones Act have been felt widely in the shipping industry. In comparison to other nations that lack such cabotage restrictions, there has been a noticeable decline in the U.S. shipping fleet. Thus, the U.S. is losing out to the competition of other nations (Brackins, 2009). 


\section{GLOBAL SHIPPING LANES}

Before we look into the advantages and disadvantages of the Merchant Marine Act of 1920, we should first describe global shipping lanes and how they have changed over time. It has long been known that Europe and the Far East have been trading goods for hundreds of years. However, as the shipping industry grew with the discovery of new ports of call, so did shipbuilding. With such increases, more and larger ships have made it to the waterways of the world. Europe is still the destination of many, but new routes with new markets have appeared.

For instance, some ships still leave the Far East, travel around Indonesia and pass through the Suez Canal to reach the Mediterranean Sea and the ports of Europe. Others simply cross the Pacific Ocean, use the United States as a land bridge (crossing by truck or rail), and travel by ship again across the Atlantic Ocean to reach Europe. Still others leave the Far East, travel through the Panama Canal and reach Europe in non-stop fashion. Figure 1 below illustrates today's major shipping lanes.

Figure 1. Major Shipping Lanes of Today (Rodrigue, Comtois \& Slack, 2009)

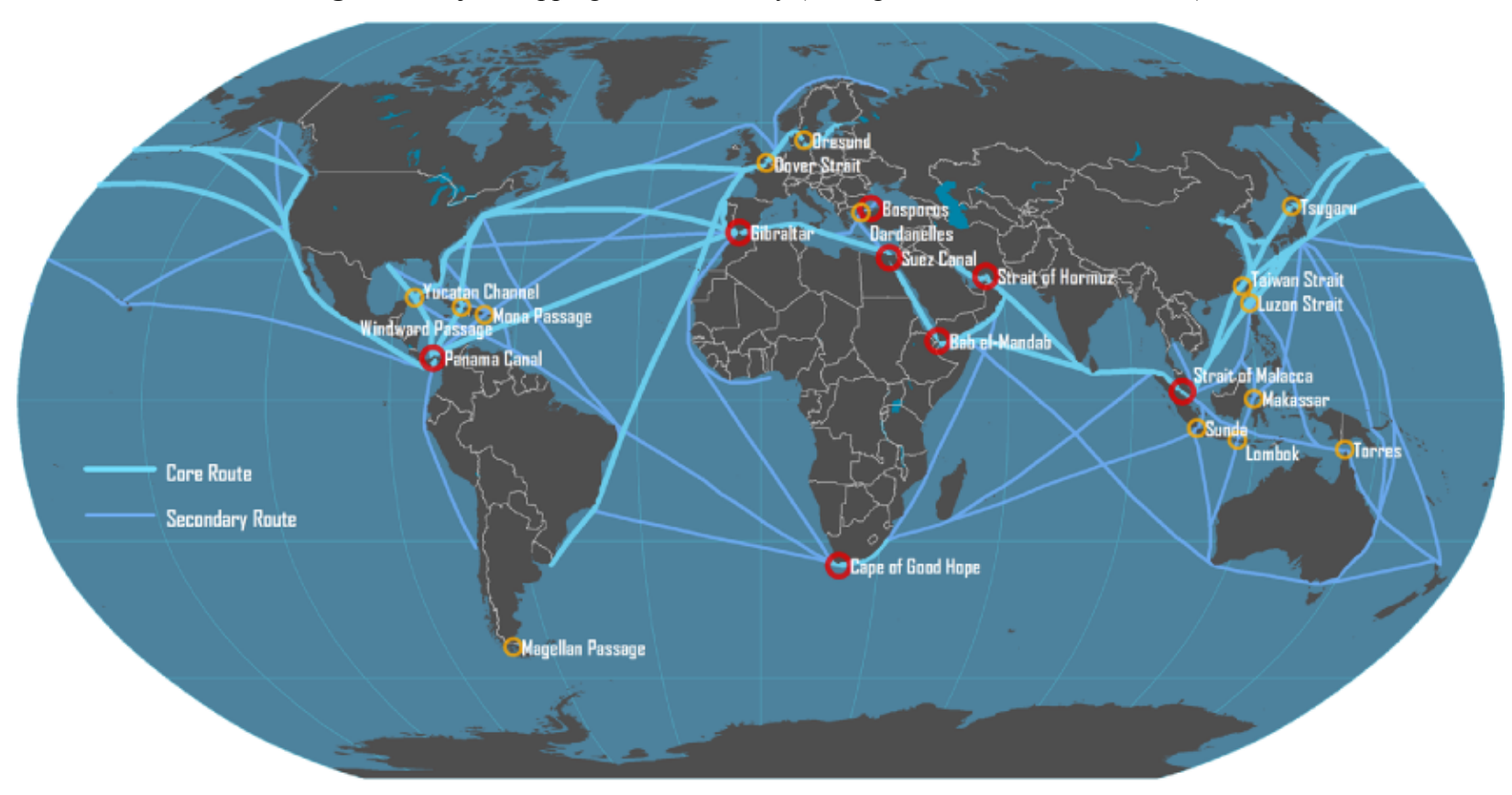

Approximately six generations of container ships have been built through the years. They have grown from carrying 500-800 containers, to approximately 11,000 to 14,500 containers (Rodrique, Comtois, \& Slack, 2009). Production of the next generation of container ships is underway, and these are expected to carry $20,000+$ containers.

The major concern now is that fewer, yet larger foreign ships are on the waterways and are only allowed a single stop at a U.S. port. Less stops by larger container ships equates to less efficient port operations and more sporadic transportation infrastructure usage. Global shipping has changed, but the Merchant Marine Act of 1920 has not kept up with the dynamics of the industry.

\section{ADVANTAGE - NAVAL DEFENSE}

First and foremost, it is important to realize that at the time in which the Jones Act was enacted, a strong, resilient merchant fleet was crucial for our country's success. The United States was recognizing its great need for a dependable defense fleet, and World War I proved their concerns true. The infant United States Navy did not possess the capability of performing all military functions, and thus relied on the civilian sector for the transport of military cargo to overseas 
destinations (Brackins, 2009). Hence, the United States Merchant Marine was a significant part of the country's naval defenses, providing transportation and logistics on the waterways of the world.

Practically no one would argue that foreign vessels should be a part of a country's naval defenses. Only allies at a time of need provide that service. Yet, as the years have moved on, the United States Navy has become one of the most complete and powerful navies in the world. Unfortunately, its supporting civilian merchant fleet has been slowly disappearing.

\section{ADVANTAGE - SHIPBUILDING (PROTECTIONISM)}

The Jones Act is really a trade and commerce law that was part of a larger Merchant Marine Act. It requires all trade delivered between United States ports to be transported in United States flagged vessels, constructed in the United States, and owned by American citizens. It is protectionism in the shipbuilding industry at its finest, but was intended as a necessary contribution to the Act at its outset. It keeps U.S. shipbuilders working and U.S. crews employed.

However, protectionism comes at a cost. Generally, manning and flagging a vessel have very little impact on total cost. Vessel costs are essentially made up of capital and operating costs. Capital costs refer to the actual vessel construction costs. Operating costs include earnings paid to the crew, fuel charges, insurance, maintenance and repair, and other administrative expenses. Of these, labor and maintenance costs are typically higher for United States vessels than for foreign-flagged vessels. United States crew costs generally account for most of the differences in operating costs between U.S. and foreign flagged vessels. For example, manning costs account for 77 percent of the operating cost differential for a typical oil tanker and 81 percent of the cost differential for a typical containership (Brackins, 2009). This is what puts U.S. sea transportation at a significant disadvantage to other foreign vessel manufacturers (Jones Act Hinders, 2010).

The Acts' effects have been felt widely in the shipping industry. In comparison to other nations that lack such cabotage restrictions, there has been a noticeable decline in the U.S. shipping fleet, losing out to the competition of other nations who have exploited such protectionism.

\section{DISADVANTAGE - COMMERCE}

While the U.S. invented the container shipping line industry in 1956, it is sadly absent from global shipping. The country that provides the biggest market for imported goods should be a leader in global shipping. Yet, the two largest U.S. owned companies, Matson and Horizon, are ranked 30 and 36 respectively, among container lines (Grapper, 2011). As long as the U.S. still insists that all domestic cargo be carried by U.S. made ships crewed by American citizens, they will continue to be surpassed. As a result of the Jones Act still being in effect, the U.S. container fleet essentially only supplies Guam, Alaska, and Hawaii (Grapper, 2011). Of the world's 41,674 cargo-carrying vessels in 2016, only 169 were U.S. registered (US DOT, 2016). It is ironic that container shipping, conceived by the U.S. and responsible for standardizing the transport of break-bulk cargo, has abandoned the U.S. due to its extreme trade protectionism.

The extreme trade protectionism imposed by the Jones Act extends well beyond U.S. borders. It has created challenges for worldwide shipping firms. Examining world leader, Maersk's container shipping routes coupled with the fact that the Jones Act only permits foreign ships to dock at one U.S. port on their journey, it is evident that the U.S. plays a role in their unwillingness to use the Panama Canal. Without the ability to dock at multiple ports on the U.S. coasts, shipping companies such as Maersk lack the economic incentive to incur the expense of traveling through the Canal.

Additionally, the restrictive nature of the Jones Act has created an economic disadvantage for use of the Panama Canal by many major shipping companies. Maersk has decided that it will exclusively use the Suez Canal to get to Europe. After that, in 2013 Maersk stopped using the Panama Canal to transport goods from Asia to the East Coast of the United States (Park, 2013). Instead, the Suez Canal permits their use of bigger ships which translates to increased profits. No doubt, larger ships with tens of thousands of containers produce less traffic on the waterways, but can require more stops along the way. So, to make up for lost revenue the Panama Canal raised its rates. The cost for passing through the Panama Canal tripled between 2009 and 2013 (Park, 2013). 


\section{DISADVANTAGE - U. S. TRANSPORTATION INFRASTRUCTURE CONGESTION}

The history of transportation in the U.S. has progressed from rivers, to rail, to highway systems. However, some think if the Jones Act were repealed the U.S. may be headed back to using our 25,000 miles of navigable waterways, or maritime highways for energy and environmental reasons. Those major waterways are located along the: U.S. West, Northeast and Gulf coasts, Great Lakes, and Mississippi River.

The major maritime highways of the past could certainly absorb already stressed rail and highway capacity. After noting that a single barge tow can carry as many as 456 twenty-foot-equivalent (TEU) containers, and that currently only 1.4 billion tons (about $2 \%$ of U.S. domestic cargo) spends time on any navigable U.S. waterway, Davis (2010) cited the following statistics regarding the underutilization of our maritime highways:

- One gallon of fuel would move one ton of cargo 60 miles by truck, 200 miles by locomotive, or 500 miles by barge - Port of Oakland.

- Congestions on our nation's highways caused urban Americans to travel 4.2 billion hours more and to purchase an extra 2.9 billion gallons of fuel for a congestion cost of $\$ 78$ billion - Texas Transportation Institute.

- One barge can replace the use of two stack trains or 350 container trucks. This relates to an annual reduction of about 238,000 tons of carbon dioxide, 2,640 tons of nitrogen oxide, 110 tons of reactive organic gases, and 15 tons of diesel particulate matter-Eco Transport.

- The cost to add one lane-mile of highway under normal conditions ranges from $\$ 2.3$ million for a small urbanized artery to $\$ 13.4$ million on a major interstate. Obviously, building more roadways when waterways are readily available is imprudent - Federal Highway Administration.

- There are roughly 155 fatalities per million ton-miles by highway transport. If transported on the maritime highway, the number of fatalities could be reduced to one-Eco Transport.

For example, ports that could benefit by reduced congestion would be the West Coast ports. The Ports of Los Angeles and Long Beach are the first and second (respectively) busiest container ports in the U.S and are the choice of many foreign shippers when given only one berthing option by the Jones Act. The Port of Los Angeles is located just north of the Port of Long Beach on the California coastline. Together, the two ports are known as the San Pedro Bay Ports. These two ports handle more than $40 \%$ of the nation's total containerized cargo import traffic and $24 \%$ of the nation's total exports (Port of Long Beach, 2007). Combined, the San Pedro ports moved 1.16 million TEUs in January 2012, up from 1.14 million a year earlier (White, 2012). For the year 2015 the two ports had a combined volume of 15.3 million TEUs, and the growth does not stop there. The two ports are expected to increase volume at an average rate of 3.9\% per year, and exceed 41.1 million TEUs by 2040 (Port of Long Beach, 2016). Then again, that forecast could actually be low. Depending on economic assumptions, the 2040 volume could fluctuate between 30.9 and 54.5 million TEUs (Port of Long Beach, 2016).

In turn, this increased traffic has led to a rise in congestion at the two bustling ports. Deep draft ports for large container ships experience delays as space for increasing volumes of import and export cargo is limited by factors such as environmental and community concerns. Congestion also occurs when vessels arrive at the same time rather than dispersed throughout the week (U.S. Department of Transportation, 2009). The time lost as a result of this bottleneck can be 3 to 6 days depending on the season (Conway Consulting, 2008). Even when ports can berth and unload ships quickly, the increasing size of container ships is moving congestion from ports to access roads, rail and highways (U.S. Department of Transportation, 2009). Such delays and congestion at the Long Beach and Los Angeles ports have shippers and receivers looking for more reliable, efficient options for transportation.

\section{SUMMARY CONCERNS AND RECENT ACTIONS TAKEN}

The Jones Act undeniably impacts the maritime community, and an examination of the issues at hand provides fuel for those both for and against its repeal. Table 1 below summarizes these pros and cons, particularly focusing on issues such as cost, control, and security. 
The Act has managed to earn media attention regarding several issues over the past years, and precedents have been set under necessity. In times of emergency, Presidents such as George W. Bush and Barack Obama have been faced with the decision of whether or not it is pertinent to waive the Jones Act to allow for outside help.

Table 1. Pros and Cons of Jones Act (Lee, 2011; Michaeli, 2014)

\begin{tabular}{l|l}
\hline \multicolumn{1}{c}{ PROS } \\
$\begin{array}{l}\text { Provides not only increases in union jobs but manufacturing } \\
\text { jobs where equipment is built }\end{array}$ & $\begin{array}{l}\text { Cost of building vessels domestically hinders transportation } \\
\text { by water between U.S. ports }\end{array}$ \\
\hline Blocks foreign control of ships & $\begin{array}{l}\text { Increases trucks on highways leading to more traffic and } \\
\text { pollution }\end{array}$ \\
\hline Has provided 40,334 vessels & $\begin{array}{l}\text { Gives competitive advantage to existing foreign ship } \\
\text { operators }\end{array}$ \\
\hline Has provided 499,676 related jobs & Higher crew costs \\
\hline Responsible for \$100.3 billion in economic output & Difficulty in finding investors who must be U.S. citizens \\
\hline $\begin{array}{l}\text { Generated \$11.4 billion in federal, state and local taxes } \\
\begin{array}{l}\text { Supports national security since U.S. ships are not } \\
\text { government subsidized }\end{array}\end{array}$ & $\begin{array}{l}\text { U.S. shipbuilding industry cannot provide enough reliable } \\
\text { ships at an affordable price to comply with Jones Act }\end{array}$ \\
\hline $\begin{array}{l}\text { Companies building tugs and barges for petroleum products } \\
\text { may go to China without Jones Act. }\end{array}$ & $\begin{array}{l}\text { U.S. is not able to take full advantage of efficient marine } \\
\text { highway system and widening of Panama Canal }\end{array}$ \\
\hline
\end{tabular}

For example, in 2005 after hurricane Katrina devastated the Gulf Coast, President Bush temporarily waived the Jones Act a mere three days after the hurricane made landfall. Only one month later, he waived the act again to allow for help after hurricane Rita. These actions allowed for the port-to-port transportation of petroleum and refined petroleum products. Again in 2012, The Department of Homeland Security decided to issue a waiver of the Jones Act to remedy the severe fuel shortages following super storm Sandy. Like before, the waiver allowed refineries along the Gulf Coast to transport fuel using foreign vessels (Robert, 2014). The waivers did not increase the total amount of fuel within the U.S., but it provided flexibility for that fuel to move as rapidly and efficiently as possible to where it was most needed (Hennessey, 2010). During other major storms and natural disasters, the Jones Act has been blamed for shortages of products and materials needed in a timely manner.

\section{POLITICAL ACTION}

On January 22, 2015, Senator John McCain introduced an amendment on the Senate floor to repeal portions of the Merchant Marine Act of 1920. His argument for the repeal of this antiquated law is that is hinders free trade while making United States industry less competitive. This, in turn, raises prices for the American consumer (McCain, 2015). His proposal, to eliminate the requirement that the United States build their own ships, supports the arguments of many oil refiners, manufacturers, and state governments. Their opposition to the Jones Act is based on the premise of protecting American jobs.

Senator McCain, who is serving as chairman of the Senate's Armed Services Committee, argues that a repeal of the Jones Act could save consumers approximately $\$ 1$ billion annually (Robert, 2014). Current legislation for the repeal is facing tough opposition based on the fact that the act protects U.S. industries from foreign competition. McCain's supporters argue that the opposite effect may be true. Based on a comparison of U.S. shipbuilding exports compared to exports of U.S. semis and trailers, shipbuilding comprises on about $2.4 \%$ of that market (Riley, 2015). There are other flaws in the logic of the Jones Act. Why does the U.S. require a ban on foreign-built vessels for commercial purposes to fulfill defense needs when there is no ban on foreign-built aircraft, cars, and trucks? In addition, the U.S. Department of Defense has leased foreign vessels to fulfill missions requiring additional sealift capacity (Riley, 2015). 
Senator McCain is unyielding in his efforts to eventually gain the needed support of the repeal. His stance is that the detrimental effects on U.S. infrastructure, transshipment of goods between domestic ports, road traffic, pollution, and U.S. investment prove that the repeal of the Jones Act ultimately benefits American consumers (Riley, 2015).

\section{CONCLUSION}

In a 1993 study, the International Trade Commission (ITC) indicated that the Jones Act costs the United States a total of $\$ 3.1$ billion per year (Boyd, 2009). If that study were repeated today, the results would likely be astounding. Using the evidence compiled above with regard to the impact of the Jones Act on the U.S., certain conclusions can be drawn about the implications of the Act today. These conclusions show, for the most part, that the Jones Act has a negative effect on the United States economy as a whole. Many will argue that it would certainly prove beneficial to remove such restriction on trade and allow for free market competition. While the benefits cannot be completely quantified, reason would indicate such benefits undoubtedly exist.

Some feel that eliminating only the "built in the United States" requirement, not the entire Jones Act, would align coastwise cabotage laws with similar laws which protect United States' airline and trucking industries. Both the trucking and the airline industries are somewhat protected from foreign competition but are not required to purchase equipment built exclusively in the United States (Jones Act Hinders, 2010).

On the other hand, proponents of the Jones Act argue that the regulations are necessary in order to maintain job protection and prevent the loss of jobs to foreign competitors, who charge less than fair wages for jobs that are similar to those performed by United States' workers. In regard to national defense, they also claim that transporting war material exclusively in United States' flagged ships is crucial to the country's overall protection and success.

Professionals in the industry agree that the U.S. is in need of a far-reaching National Transportation Plan (Bowman, 2007). Whether this sentiment is true or not, it is no secret that the Jones Act has been the source of many concerns of people in the United States today. Is it simply a regulation meant to strengthen our military and protect our seamen and shipbuilders, or does the Jones Act contain provisions that simply do not align with today's economy anymore?

Finally, most economists will agree that barriers to free trade reduce a country's standard of living. In their eyes, it might be time to remove the protectionism barriers of the Merchant Marine Act of 1920 and let the markets take over.

\section{AUTHOR BIOGRAPHIES}

Dr. Rachelle Cope is a Professor of Information Systems at Southeastern Louisiana University in Hammond, Louisiana. She received a Ph.D. in Business Administration in 1996 from Louisiana State University with a concentration in Information Systems and Decision Sciences. She teaches courses in Business Statistics, Principles of Supply Chain Management, and Data Management for Business. Her research interests include analytics, software reliability improvement warranties, dynamic storage reallocation, linear Diophantine analysis, knowledge management, and organizational citizenship behavior. Contact her at Rachelle.Cope@selu.edu.

Dr. John Woosley is an Associate Professor of Operations Management at Southeastern Louisiana University in Hammond, Louisiana. He received a Ph.D. in Business Administration in 2009 from Louisiana State University with a concentration in Information Systems and Decision Sciences. He teaches courses in Principles of Supply Chain Management and Production and Operations Management. His research interests include inventory control, shipping and logistics in supply chains, supply chain management and competitive advantage in service industries, and healthcare information systems. Contact him at John.Woosley@selu.edu.

Dr. Robert Cope is a Professor of Operations Management at Southeastern Louisiana University in Hammond, Louisiana. He received a Ph.D. in Business Administration in 1998 from Louisiana State University with a concentration in Information Systems and Decision Sciences. He teaches courses in Business Statistics, Project Management, Principles of Supply Chain Management, Production and Operations Management, and Logistics Management \& Transportation. His research interests include resource optimization techniques, scheduling, energy modeling, project management, statistical modeling, and the design of information technology. Contact him at Robert.Cope@selu.edu. 


\section{REFERENCES}

1800JonesAct (2008). The Jones Act U.S.C. Title 46 (Recodified 2006). Retrieved July 14, 2008 from http://www.1800jonesact.com/ maritime_statutes/default.asp

Bowman, R. (2007). A road to ruin? U.S. transportation infrastructure is a system in crisis. Global Logistics and Supply Chain Strategies, October, 28-35

Boyd, L. (2009). The Jones Act: What does it cost? Retrieved July 5, 2010 from www.hawaii.edu/uhwo/clear/home/jonesact.html Brackins, D. (2009). The negative effects of the Jones Act on the economy of Hawaii. Retrieved July 25, 2010, from http://www.hawaiiliberty chronicles.com/?p=2237

Conway Consulting (2008) Cargo Case Study - Port San Antonio. Retrieved November 22, 2011, from http://www.portsanantonio.us/StoreImages/collateral/lazarocardenas-pg1-2.pdf

Davis, A. (2010, December/January). Short sea shipping. WWS/World Wide Shipping, pp. 16-18

Grapper, J. (2011, February 23) Bye-bye, American shipping lines. Financial Times. From https//www.ft.com

Hennessey, K. (2010) How to waive the Jones Act. Retrieved July 24, 2010 from http://keithhennessey.com/2010/06/18/how-towaive-the-jones-act/

Jones Act Hinders Short Sea Shipping. (2010). Kennebec Captain, Blog. Retrieved November 20, 2011, from http://kennebeccaptain.blogspot.com/2010/07/jones-act-hinders-short-sea-shipping.html

Lee, R. (2011, May 12). Shipping execs argue pros and cons of Jones Act. Stamford Advocate.com

McCain, J. (2015, January 13). Press Release: "Senator John McCain files amendment to repeal The Jones Act." from http://www.mccain.senate.gov/public/index.cfm/2015/senator-john-mccain-files-amendment-to-repeal-the-jones-act

Michaeli, D. (2014, June). Foreign investment restrictions in coastwise shipping: A Maritime mess. New York Law Review. pp. 1048-1087

Park, K. (2013, March 11). Maersk Line to dump Panama Canal for Suez as ships get bigger. Bloomberg Business Week. From http://www.bloomberg.com

Port of Long Beach (2007). Ports impact on economy growing. Retrieved November 10, 2011, from http://www.polb.com/news/displaynews.asp?NewsID=137

Port of Long Beach (2016). San Pedro Bay cargo volume projected to top 41 million TEUs by 2040. Retrieved December 16, 2016, from http://www.polb.com/news/displaynews.asp?NewsID=1527\&TargetID=42

Riley, B. (2015, January 16). Senator McCain's Jones Act Amendment: Good for America. The Daily Signal. From $\mathrm{http} / / /$ dailysignal.com/2015/01/16/senator-mccains-jones-act-amendment-good-for-america/

Robert, J. (2014, December 5). Senator McCain vows Jones Act will be repealed one day. Reuters. From www.reuters.com/article/2014/12/05/us-usa-jonesact-mccain-idUSKCNOJJ24Q20141205

Rodrique, J-P., Comtois, C., \& Slack, B. (2009). The geography of transport systems (Second Edition), New York City, New York: Routledge (Taylor \& Francis)

Smith, S. (2010). What is the Jones Act? WiseGeek. Retrieved July 13, 2010 from http://www.wisegeek.com/what-is-the-jonesact.htm

U.S. Department of Transportation (2009) Freight management and operations. Retrieved October 20, 2011 from http://ops.fhwa.dot.gov/freight/freight_analysis/freight_story/congestion.htm

U.S. Department of Transportation (2016). Table 1-24: Number and size of the U.S. Merchant Fleet and its share of the world fleet. Bureau of Transportation Statistics for year 2016. From https://www.rita.dot.gov $>$ bts $>$ file $>$ html

White, R. (2012, February) L.A., Long Beach ports complex posts best January since recession. Retrieved January 30, 2012, from http://www.latimes.com/business/la-fi-ports-20120216,0,2446476.story 


\section{NOTES}

